\title{
Gulf war clouds convention
}

\section{Washington \& London}

As international negotiating teams arrive in Washington this week to begin hammering out what could be the most ambitious international environmental treaty ever, hopes for smooth sailing have been dimmed by news that many developing nations may not attend. Also absent may be President George Bush, the host, who may be forced by the Gulf conflict not to deliver his planned opening address, that has been eagerly awaited for signs of possible changes in US policies on global warming.

Even without added international tensions, next week's meeting of the Intergovernmental Negotiating Committee on a Framework Convention on Climate Change was going to be a difficult balance of diplomacy and science. Organized by the United Nations, it is meant to build from last year's assessment Intergovernmental Panel on Climate Change (IPCC) and produce a framework convention.

The meeting starts negotiations towards a treaty first to cut emissions of greenhouse gases worldwide and then to reverse their increase in recent decades. Participants will have to agree to tolerate considerable scientific and economic uncertainty - which the United States has so far resisted - and to accept painful changes and even cuts in energy use.

The possible absence of many developing nations next week will complicate the process. A UN General Assembly resolution at the end of last year set up a small trust fund to assist delegates from poor countries and the small island states most threatened by a rising sea level. But in the short time since and because of the distractions of war, few contributions have yet been made. The organizers fear that it is now too late for some countries to attend, and that the disruption of commercial airline flights around the Middle East can only make things worse.

Procedural issues are expected to dominate the ten-day negotiating session from 4 to 14 February. Although UN officials are trying to anticipate the administrative difficulties, they acknowledge that fractious debate over the membership of working groups and even the seating arrangements could consume the entire meeting, especially if the developing countries believe themselves to be under-represented.

Strong leadership would help, but may be in short supply. Although the United States is hosting the convention, US officials stress that they are participants like any others and will not try to run the show, a position taken to avoid charges of bullying such as have occasionally arisen in previous international environmental negotiations.
The organizers hope to fill the leadership vacuum by appointing an international committee to steer the negotiations, but even that plan is controversial. The industrialized countries of the West favour a small steering group, with five or so members, where their interests would predominate. Developing nations have other thoughts.

Given the likely diplomatic squalls, hopes that the Washington meeting will produce an early draft of a framework climate convention seem unfounded. Although there is supposed to be a document for signature at the 1992 UN Conference on Environment and Development, to be held in Brazil, no country is likely to table a formal proposal until a negotiating structure is established.

Next week's meeting may accomplish that, at least. Working groups will be set up to negotiate individual sections of a convention, to deal with the legal problems and with the transfer of technology to developing countries. Some participants plan to argue for a parallel set of working groups to agree on prompt cuts in carbon dioxide and other greenhouse gases, but are likely to be opposed by the powerful US delegation.

Given the success of the Vienna Convention on the protection of the ozone layer and the Montreal Protocols attached to it, a similar structure is now the favoured model for a climate treaty, despite the differences between the two problems in scope and depth of current scientific understanding.

Critics of the Vienna-Montreal model argue that, compared with the probable costs of large carbon dioxide cuts, the economic costs of the $\mathrm{CFC}$ reductions required at Montreal are small. And, in marked contrast with current disagreements on global warming, governments and (eventually) chemical industries were largely in favour of CFC limits when the Montreal Protocols were completed.

Even so, as Pamela Wexler of the University of Maryland Center for Global Change remarks, people - and even environmental diplomats - tend to stick with what they know best. And "A lot of people made their reputations on the Montreal Protocol", she says. A new book from the World Resources Institute* collects a number of alternative models from some of the veterans of international environmental diplomacy. Whether next week's meeting will escape from housekeeping long enough to consider them remains to be seen.

Christopher Anderson \& Peter Aldhous

* Greenhouse Warming: Negotiating a Global Regime (World Resources Institute, 1991).

\section{Doors are opened to advanced study}

\section{Munich}

Two new 'institutes for advanced study' were announced independently earlier this month in Budapest and Prague. Both institutes bear the name of the renowned Princeton institute, and they share the aim of slowing the alarming brain-drain in the region, but the similarities end there.

The Budapest institute, known as the 'Collegium Budapest', is meant to perform a bridging function with the rest of the scientific world and at the same time address some of the most acute problems in the region. It will focus at first on pressing problems such as the transformation of planned economies into market economies and interdisciplinary environmental research. Later, the Collegium might shift its focus more to natural sciences.

Beginning in the autumn of 1991, up to 15 scholarships a year will be made available to researchers from both Eastern Europe and the West; both established researchers and promising younger researchers will be eligible to apply.

The Collegium, which will be financed initially by a variety of Western European governments and foundations through the Ernst Reuter Foundation in Berlin, will be built up along the lines of the Wissenschaftskolleg, a 10-year-old 'institute for advanced study', which is in turn modelled on the eponymous institute in Princeton. A broad spectrum of political parties as well as the Hungarian Academy of Sciences have promised to support the Collegium, which will be centrally located in a former Carmelite cloister in the Buda area, where all researchers can work and some may be housed.

The Prague Institute for Advanced Study (PIAS), which hopes to open its doors within 18 months according to coordinator Petr Pechan, is intended to be a centre of excellence that can help Czechoslovakia hang on to its best researchers in natural and environmental sciences. PIAS will offer posts of two to three years duration to researchers in a number of fields as well as research grant money. Areas considered include biomaterials, peptide chemistry, environmental medicine and molecular biology, but the final decisions will depend on the success of recruitment.

Universities and research institutes in both the Czech and Slovak parts of the country have thrown their support behind PIAS, says Pechan, a Czech-born biomedical researcher who returned last year after 22 years abroad. They are less afraid of losing their most talented people to PIAS, he says, than they are of people leaving the country entirely. But Pechan is still trying to attract firm offers from Western organizations that could guarantee the future of the institute.

Steven Dickman 